Published in final edited form as:

Cancer Treat Res. 2010 ; 156: 25-39. doi:10.1007/978-1-4419-6518-9_3.

\title{
Gamete Preservation
}

\section{Susan L. Barrett and Teresa K. Woodruff}

S.L. Barrett (B) Department of Obstetrics and Gynecology, Feinberg School of Medicine, Northwestern University, Chicago, IL, USA; Center for Reproductive Science, Northwestern University, Evanston, IL, USA; The Oncofertility Consortium, Northwestern University, Chicago, IL, USA

Susan L. Barrett: susan-barrett@northwestern.edu

\section{Introduction}

With the increase in survivorship following cancer for women in their reproductive years, as well as an increase in survivorship with childhood cancers, there is a demand for perfecting current fertility preservation methods and generating new options for patients who are unable to pursue the conventional course of fertility treatments. Cryopreservation using a slow-cooling method for embryos is currently the standard-of-care for women wishing to preserve their fertility; other options, such as oocyte cryopreservation and embryo vitrification, have become increasingly accepted methods of fertility preservation.

As important as oocyte and embryo cryopreservation methods are for preserving fertility, some patients may be too sick or too young to undergo fertility treatments or have hormonesensitive cancers that preclude standard approaches; therefore, other preservation options must be explored. Ovarian tissue cryopreservation followed by ovarian tissue transplant and follicle cryopreservation followed by in vitro follicle maturation are experimental techniques that have shown promising results. This chapter will discuss current methods of gamete preservation as well as new, experimental options to preserve immature gametes. An overview of ovarian biology, as well as the science of cryobiology, is discussed to help the reader better understand the circumstances under which different techniques may be used.

\section{Organization of Gametes in the Human Ovary}

The human ovary is divided into three main areas (Fig. 3.1): the hilum, the inner medulla, and the outer cortex. The hilum is the area attached to the mesovarium and it is the entry point for nerves and blood vessels serving the ovary. The medulla is the central vascular region of the ovary that nourishes immature and growing follicles with necessary hormones and gas exchange. The ovarian cortex, which is approximately $2-3 \mathrm{~mm}$ thick and surrounds the central medulla, contains all immature and growing germ cells as well as supportive and endocrine hormone-producing cells. The dense outer layer of the cortex, just under the surface epithelium, is called the tunica albuginea and is filled with dense connective tissue that gives support to the primordial follicle population.

At the time of birth, the human ovary contains the total number of germ cells it will need and use through the reproductive years [1-4]. At this time, all germ cells exist as immature oocytes inside primordial follicles, the smallest functional units of the ovary. Each follicle is comprised of an oocyte surrounded by few interconnected squamous epithelia cells and a basal lamina. In a prepubescent ovary, primordial follicles are scattered throughout the cortex with the majority of the follicles residing near the outer edge of the ovarian cortex [5]. During childhood, low levels of gonadotropins stimulate some of the follicles to exit the arrested primordial state and begin the process of follicle growth; however, these follicles 
become atretic and do not produce mature oocytes $[6,7]$. It is not until the onset of puberty that selected primordial follicles undergo follicle growth, or folliculogenesis, in a cyclic fashion.

In folliculogenesis, the growth of selected follicles proceeds from the primordial to primary follicle stage, during which the squamous epithelium becomes cuboidal in shape and proliferates to form one complete layer of follicle cells. At this time, the central oocyte also begins to grow and secrete proteins on its surface, generating a protective shell called the zona pellucida [8]. The follicle continues to grow with proliferation of follicle or granulosa cells to form multiple cell layers surrounding the oocyte, which in turn stimulate the growth of the oocyte by producing paracrine factors and forming physical cell-cell interactions. As the follicle increases in size, the antral cavity forms, separating the follicle cells into two distinct types of supportive cells, the mural and cumulus granulosa. The mural granulosa remain toward the outer edge of the follicle and express an abundance of luteinizing hormone (LH) receptor, which is essential for ovulation in response to the LH surge. These cells, in conjunction with the theca cells that surround the follicle externally, are essential for aromatization (or conversion) of testosterone to estradiol [9]. The cumulus granulose cells stay connected to the oocyte and support and nourish the growing oocyte by transporting necessary molecules such as amino acids [10, 11], cAMP [12, 13], glucose [14], and pyruvate [15] through gap junctions. As follicles grow, the fluid filled antral cavity expands, pushing outward and reaching preovulatory sizes of $12-15 \mathrm{~mm}$ in diameter. These mature follicles contain oocytes that are capable of resuming meiosis and undergoing fertilization $[4,16]$. For an excellent review on hormone regulation in follicular development, see Zeleznik et al. [17].

\section{Cryopreservation Techniques}

Cryopreservation holds tissues at temperatures between -140 and -200 !C , at which no biological activity can occur, producing a state of "suspended animation" of tissues that can be maintained indefinitely [18]. It is the process of cooling and warming, not long-term cryo-storage, that harms cells or tissue [19]. Currently, there are two main approaches for cryopreservation: slow-cooling and vitrification. The success of either of these approaches depends upon the tissue, the cryoprotectant, and the freezing vessel used.

The most important hurdle in cryopreservation is avoiding the phase transition between water and ice inside the cell. Because water is everywhere in a cell and is important for the function of macromolecules and larger structures such as lipid membranes, the formation of large ice crystals upon cooling destroys cellular components and ruptures intact membranes [20]. Interestingly, pure water will supercool substantially and form ice only at approximately -39 !C [18], which is much lower than the temperature at which ice is thermodynamically stable $(<0$ !C). Impurities, such as dust, act as ice nucleators, initiating large crystal formation at temperatures well above -39 !C [18]. However, allowing ice crystals to form at temperatures more than a few degrees below zero during cooling has been shown to damage embryos and oocytes [21]. To initiate crystal formation in a solution at higher temperatures, the solution must be seeded with ice either by the addition of an ice crystal or by touching it with something colder, such as a forceps dipped in liquid nitrogen, as is done in the laboratory. As ice crystals grow, the volume of the unfrozen solution decreases, thus increasing the concentration of solutes (e.g., salt), which not only helps to reduce ice formation inside the cell but also severely dehydrates cells and can cause cell damage and death [22-24].

Cryoprotectants are defined functionally as any compound that increases cell survivability when used in a cryopreservation method. There are many different types of cryoprotectants, 
including alcohols, sugars, oils, and starches, and each type acts through different mechanisms. However, a good cryoprotectant is one that can preserve cell structures and is not toxic. James Lovelock first described the mechanism of action of cryoprotectants in his experiments showing that erythrocytes (red blood cells) freeze at lower temperatures when combined with glycerol. He found that the increase in salt concentration resulting from ice crystal formation causes hemolysis [25, 26]. His work highlights the delicate balance between the many factors that must be considered when developing a successful cryopreservation method.

Currently, there are three widely used permeating cryoprotectants in fertility preservation: dimethyl sulfoxide (DMSO), ethylene glycol (EG), and propylene glycol (PG). These cryoprotectants have similar properties: solubility in water at low temperatures, cell permeability, and relatively low toxicity. However, each of these cryoprotectants also has different degrees of membrane permeability, as has been shown with mammalian oocytes [27-29]. Mouse oocytes seem very hearty and are capable of being cryopreserved using several different cryoprotectants; however, evidence suggests that EG is less toxic to mouse oocytes that have resumed meiosis and reached metaphase-II (MII) [30-32]. In contrast, rhesus monkey oocytes are much more sensitive to cryoprotectants and have been shown to be less permeable to glycerol than to PG, EG, and DMSO, and at room temperature, the oocytes are more permeable to PG than to the other cryoprotectants [28, 33]. Interestingly, it was found that PG causes potentially lethal effects when used in human oocyte cryopreservation protocols designed for DMSO. By incubating oocytes in PG at a higher incubation temperature for a shorter time, it may be possible to prevent oocyte lysis [34].

Conventional cryopreservation is the process of slow-rate freezing in which a relatively low concentration of cryoprotectant is used (!1.5 (M)olar), showing little toxicity to cells or tissue [35]. As cryoprotectant is added to cells, it results in initial cellular dehydration followed by a return to isotonic volume with the permeation of cryoprotectant and water. Generally, cells are cooled slowly using a controlledrate freezing machine, which allows samples to be cooled at various rates; ovarian tissue is generally cryopreserved at $2^{\circ} \mathrm{C} / \mathrm{min}$ prior to ice seeding and $0.3^{\circ} \mathrm{C} / \mathrm{min}$ after crystallization to ensure the tissue is dehydrated before intracellular ice formation occurs. Optimal rates to minimize intracellular ice formation vary among cell and tissue types; for example, stem cells survive better at a freezing rate of $1^{\circ} \mathrm{C} / \mathrm{min}$ and red blood cells at a rate of $1,000^{\circ} \mathrm{C} / \mathrm{min}$ [35].

As mentioned above, extracellular ice nucleation is triggered manually and must be performed above the temperature of intracellular ice formation. The temperature at which optimal nucleation is performed is determined by the cryoprotectant used as well as the characteristics of the cells [36]. It has been shown that the optimal seeding temperature for human oocytes [36] is different from that for primate [37] and mouse oocytes [38, 39] and varies depending on the meiotic stage of the oocyte [36].

Slow cryopreservation has been used for a number of years; however, in some instances, it can be inconsistent and require expensive equipment. More recently, the process of vitrification has shown to be more successful for some cell and tissue types. Vitrification is a process that uses very high rates of cooling, so fast that water is solidified without crystallization, "like glass." Some investigations of vitrification have shown that extremely high concentrations of cryoprotectants do not crystallize when cooled, even if it is done slowly. This approach is attractive from a technical standpoint; unfortunately, cyroprotectant solutions are toxic to cells at very high concentrations. Solute toxicity is a major drawback of using vitrification for preservation, even with high cooling rates. To reduce toxicity, concentrations of cryoprotectants can be lowered as long as cooling is fast enough to preclude ice formation. For example, the cooling rate for embryos exposed to $8.5 \mathrm{M}$ 
ethylene glycol must be at least $100,000 ! \mathrm{C} / \mathrm{min}$ for vitrification to occur [40]. To achieve an extremely rapid rate of cooling, a small volume of solution must be used. Recently, specialized storage devices designed to achieve rapid rates of cooling have been designed for the vitrification of eggs and embryos. They hold a very small volume of solution, usually less than $1 \mu$. These devices have various configurations; the ideal device is covered by a thin wall of plastic and can be submerged directly into liquid nitrogen, thus maximizing the cooling rate. Vitrification is more difficult for sizeable tissue samples that require larger amounts of cryosolution, simply due to the inability to be cooled so quickly.

Although many cells and tissues can be successfully cryopreserved using slow-freeze methods or vitrification methods without intracellular ice formation and can be stored in liquid nitrogen indefinitely, there is still a risk of ice formation during the thawing process if it is conducted improperly. If samples are thawed slowly, ice crystals can form and/or grow causing more damage; however, if samples are thawed rapidly enough, there is little time for ice nucleation and growth to occur [41, 42]. After thawing, there is further risk of damage during the course of removing cryoprotectants. If cells are immediately put into a significantly lower concentration of cryoprotectant, water will rapidly move into the cell and the cells can swell and burst. Therefore, it is usually advised that a series of decreasing concentrations of cryoprotectant is used to slowly remove the cryoprotectants and gently rehydrate cells. As an alternative, it can also be very effective to use a non-penetrating cryoprotectant such as sucrose to reduce osmotic shock during the step-down process [43].

\section{Embryo and Oocyte Cryopreservation}

During the course of the last 55 years, the science of reproductive biology, namely in vitro fertilization (IVF), has coincided with the ability to preserve embryos and oocytes [18]. The storage of gametes is no longer reserved for infertile couples; it now exists as an option for women who wish to preserve their fertility for various reasons. With advances in oncology and anti-cancer therapy, more reproductive age women are surviving cancer. Unfortunately, many anti-cancer regimens and treatments for other diseases, such as autoimmune disorders, are gonadotoxic $[44,45]$. Depending on the diagnosis, some women are able to postpone treatment and proceed through ovarian stimulation in order to collect oocytes from preovulatory follicles for either oocyte cryopreservation or fertilization and subsequent embryo cryopreservation.

During the last 30 years, ovarian stimulation protocols have been perfected, sometimes generating numerous mature oocytes. Prior to the development and use of cryopreservation in the clinic, women were limited in the number of oocytes they were able to fertilize and had to discard excess gametes [46]. Today, a large number of embryos are cryopreserved as standard-of-care in order to avoid unnecessary rounds of hormone stimulation. Cryopreservation of embryos and oocytes are the best options for pursuing a family for women undergoing fertility preservation, with or without a cancer diagnosis $[47,48]$. The first successful embryo cryopreservation was performed with eight-cell mouse embryos in $1972[49,50]$, and it took less than a decade after the birth of Louise Brown [51] for the successful cryopreservation and re-implantation of a human eight-cell embryo [52-54]. Since then, protocols have been developed and proved successful for cryopreservation of human embryos of all developmental stages [52, 53]. The survival rate for slow-rate cryopreservation is approximately $75 \%$, with a pregnancy rate between 20 and $30 \%$ per transfer [55]. Though vitrification of embryos has been reported to have a $90 \%$ survivability rate and a higher pregnancy rate than slow-freeze protocols, it has not yet replaced conventional methods of embryo cryopreservation $[56,57]$. 
Although embryo cryopreservation has been successful, there are situations in which oocytes must be cryopreserved. Cryopreservation of oocytes not only avoids ethical issues surrounding the preservation and long-term storage of embryos but is ideal for women who do not have a male partner or sperm donor at the time of ovarian stimulation. However, cryopreservation of oocytes has been shown to be much more complicated than cryopreservation of embryos. Approximately $50-65 \%$ of oocytes survive slow-rate freezing, and they are usually damaged from intracellular ice formation due to their large cytoplasmic volume [58]. The majority of oocytes that are cryopreserved are mature, aspirated from large preovulatory follicles, but they are not fertilized in vitro. They are arrested at MII, at which point the oocyte contains a small spindle of microtubules that aligns the maternal chromosomes. Unfortunately, this spindle is extremely sensitive to changes in temperature, which results in the depolymerization of microtubule fibers. Upon the thawing process, microtubules attempt to repolymerize, resulting in abnormal spindles and misaligned chromosomes $[33,59,60]$. In the last few years, new protocols, including the development of vitrification methodologies, have increased the survivability of cryopreserved oocytes up to $80 \%$ [61, 62].

Another source of oocytes for gamete preservation is ovarian tissue removed for ovarian tissue cryopreservation. Large follicles $! 1 \mathrm{~mm}$ can easily be seen on the ovarian cortex and follicles greater than $5 \mathrm{~mm}$ may be aspirated to obtain immature cumulus-oocyte complexes. As the ovarian tissue is processed (discussed below), smaller antral follicles rupture releasing oocytes that fall to the bottom of the dish ranging in size and quality from incompetent denuded oocytes to larger cumulus enclosed oocytes (Fig. 3.2a). Oocytes are collected from the bottom of every dish used and matured in vitro for up to $40 \mathrm{~h}$. By $24 \mathrm{~h}$ in culture the cumulus granulosa, surrounding the oocyte, begins to mucify resulting in cumulus cell differentiation and expansion (Fig. 3.2b). By 40 h, oocytes are stripped of cumulus cells and are examined for meiotic stage (Fig. 3.2c); the resulting MII oocytes are vitrified for potential future use. Although there have been numerous reported pregnancies with in vivo matured cryopreserved oocytes [63-66], there have been few pregnancies using vitrified in vitro matured oocytes and no pregnancies have been reported with in vitro matured oocytes preserved by slow-rate cryopreservation [63, 64, 67].

\section{Experimental Options for Gamete Preservation}

During the last few years, there has been great progress in the field of oncofertility. Much research has been done in this field with the hope of broadening the range of fertility preservation options and for women facing potentially gonadotoxic treatments.

\section{Ovarian Tissue Cryopreservation and Transplantation}

Not all women are able to delay anti-cancer regimens for the 2-5 weeks needed to undergo hormonal stimulation to preserve mature oocytes or embryos. Other options have been developed to preserve gametes in order to restore fertility in women after treatment. Ovarian tissue cryopreservation and subsequent tissue transplant is still an experimental procedure that involves the removal of an ovary or piece of cortical tissue (Fig. 3.3a), which is cut into small pieces (Fig. 3.3b) that are cryopreserved until a woman chooses to restore her fertility. It is currently the only methodology that is feasible for fertility preservation in young girls $[67,68]$. As mentioned previously, the cortex of a normal ovary is filled with arrested, immature, primordial follicles; there may be hundreds of primordial follicles in a 1-mm3 piece of tissue [69]. Analysis of human ovarian cortical tissue has shown that the number of primordial follicles varies in the ovarian cortex and is directly correlated with a woman's age [70]. Unlike freezing embryos and mature oocytes, which contain large cytoplasmic volumes, the primordial follicles in cortical tissue contain small oocytes that easily survive the freezing process when the tissue is cut into small strips of $1-2 \mathrm{~mm} \times 1-2 \mathrm{~mm} \times 10 \mathrm{~mm}$ 
(Fig. 3.3b). Ovarian tissue transplant following tissue cryopreservation was first successfully completed in mouse [71, 72] and has since been successful in sheep [73] and primates, whose ovaries more resemble those of humans [74]. In the last few years, more than 30 cases have described the transplantation of cryopreserved or vitrified tissue to heterotopic sites such as the forearm [75], as well orthotopic sites such as the abdomen [76] or back to the residual ovary [77, 78]. It was found, on average, that hormone cyclicity resumed within 3 and 5 months of the ovarian tissue transplant, which represents the time it takes for follicle recruitment and subsequent growth $[77,79,80]$. Ovarian tissue transplantation has resulted in the birth of six children to date [77, 78, 81]. Although several groups have reported high levels of follicle-stimulating hormone (FSH) after transplant, which is associated with a low follicular reserve $[79,82]$, it is still too early to tell how long these transplants will remain functional. It is hypothesized that a single transplant could last several years depending on the age at which the tissue was removed as well as tissue exposure to gonadotoxic treatment prior to removal $[83,84]$. For an excellent, in-depth review of ovarian tissue transplant see Demeestere et al. [85].

\section{In Vitro Follicle Cryopreservation and Maturation}

There are situations in which women diagnosed with hematologic or ovarian diseases or who have been diagnosed with BRCA1/2 positivity are unable to transplant their stored ovarian cortical tissue due to the possibility that the tissue may contain microscopic lesions $[86,87]$. In addition, options for fertility preservation are only available for mature oocytes, embryos, and tissue containing primordial follicles, completely ignoring the vast number of growing yet immature gametes contained within the ovary in primary and early secondary follicles. Experimental studies of individual follicle cryopreservation and subsequent in vitro follicle maturation tackle this last remaining population of female gametes for use in fertility preservation.

As cortical tissue is isolated from the ovary, it can be cut into thin strips and cryopreserved as mentioned above; however, due to their increased oocyte size, primary and secondary follicles fail to survive the in situ freezing process $[19,88]$. It is hypothesized that individual follicle isolation allows for better penetration of cryoprotectants, thus helping to stabilize physical connections between the follicle cells and the oocyte [89]. Therefore, a portion of cortical tissue can be cut into smaller pieces $(2 \mathrm{~mm} 3)$ and treated with enzymes such as liberase or collagenase that will break down stromal tissue to aid in the release of small follicles (Fig. 3.4) [90-92], which then can be cryopreserved for later use. Successful slowrate cryopreservation of small secondary follicles has been shown in mice $[89,93]$, as well as in non-human primates and humans [89].

After thawing, individual follicles can be encapsulated into a 3D matrix such as alginate, a hydrogel made from seaweed, which supports free passage of amino acids and secreted hormones and also serves as a scaffold for follicular development [94]. It has been shown that fresh isolated follicles from prepubescent mice are capable of follicle growth from 150 to $350 \mu \mathrm{m}$ within 8 days of culture in alginate [95]. These follicles secrete estradiol and progesterone at elevated levels upon antrum formation, which correlates with an increase in Star and Cyp19al gene expression necessary for steroid production and is characteristic of healthy follicles [96]. Within 8-10 days of follicle growth in the 3D matrix, follicles can be stimulated with FSH and LH to resume meiotic maturation and cumulus expansion, and the oocyte can then be fertilized, giving rise to healthy offspring [92]. Thus far, cryopreserved mouse follicles are capable of full follicle development in the 3D alginate matrix, producing healthy oocytes that can be fertilized and support embryonic development up to the blastocyst stage [89]. 
Recently, mouse protocols have been adapted for long-term culture of nonhuman primate and human follicles. It is thought that since a primate follicle takes much longer than a mouse follicle to grow from primordial follicle to a preovulatory follicle ( $>90$ days), the same would be true in in vitro culture [97]. Thus far, 30-day cultures have succeeded for both rhesus macaque [98] and human [99] secondary follicles encapsulated in alginate hydrogel. Primate follicles isolated from either the follicular phase or the luteal phase of the menstrual cycle were able to grow during a 14-day culture period; however, follicular phase follicle survival (78\%) was much higher than that of luteal phase follicles (42\%), which could be attributed to the larger size of follicles isolated in the follicular phase [98].

Encapsulated human secondary follicles isolated from ovarian tissue donated from cancer patients have also been successfully cultured for up to 30 days, with follicles forming large antral cavities and reaching sizes greater than $1 \mathrm{~mm}$ [99]. Follicle peptide and steroid hormone production appears to mimic that of antral follicles in vivo, with a characteristic increase in inhibin A and anti-Müllerian hormone (AMH) during follicle growth. Follicles that continued to grow showed a decrease in inhibin $\mathrm{B}$, which correlates with dominant, preovulatory follicle selection. Thus far, 30-day human follicle cultures are capable of supporting the growth of full-sized oocytes that are competent for fertilization (i.e., MII stage) [99].

Primate and human secondary follicle growth in culture has also been tested following individual follicle cryopreservation [89]. Although primate and human secondary follicles are able to survive the cryopreservation process and grow from an average $175-250 \mu \mathrm{m}$ (primate) and 125-200 $\mu \mathrm{m}$ (human) during a 6-day culture period, the length of the culture period must be extended in order to see the full effects of cryopreservation on oocyte development [89]. Isolation and cryopreservation of individual secondary follicles expands option for women and children who cannot immediately seek fertility treatments and are not good candidates for other fertility sparing options such as ovarian tissue cryopreservation.

\section{Conclusion}

There have been great advances in gamete preservation both for infertile couples and for women and young girls who are faced with life-threatening diseases. Perfecting oocyte and embryo cryopreservation as well as developing new procedures, such as ovarian tissue cryopreservation/transplant and follicle cryopreservation followed by in vitro follicle maturation, is expected to generate more options for fertility preservation.

\section{Acknowledgments}

We thank Steve Mullen, Ph.D., for his critical review and input on the cryopreservation section. This research was supported by the oncofertility consortium NIH 8UL1DE019587, 5RL1HD058296. The content is solely the responsibility of the authors and does not necessarily reflect the official views of the National Institutes of Health.

\section{References}

1. Baker TG. A quantitative and cytological study of germ cells in human ovaries. Proc R Soc Lond B Biol Sci. 1963; 158:417-33. [PubMed: 14070052]

2. Baker TG, Sum W. Development of the ovary and oogenesis. Clin Obstet Gynaecol. 1976; 3(1):326. [PubMed: 1009717]

3. Faddy MJ. Follicle dynamics during ovarian ageing. Mol Cell Endocrinol. 2000; 163(1-2):43-8. [PubMed: 10963872]

4. Gougeon A. Dynamics of follicular growth in the human: a model from preliminary results. Hum Reprod. 1986; 1(2):81-7. [PubMed: 3558758]

5. Sforza C, Vizzotto L, Ferrario VF, Forabosco A. Position of follicles in normal human ovary during definitive histogenesis. Early Hum Dev. 2003; 74(1):27-35. [PubMed: 14512179] 
6. Macklon NS, Fauser BC. Aspects of ovarian follicle development throughout life. Horm Res. 1999; 52(4):161-70. [PubMed: 10725781]

7. Peters H, Himelstein-Braw R, Faber M. The normal development of the ovary in childhood. Acta Endocrinol (Copenh). 1976; 82(3):617-30. [PubMed: 947131]

8. Zhao M, Dean J. The zona pellucida in folliculogenesis, fertilization and early development. Rev Endocr Metab Disord. 2002; 3(1):19-26. [PubMed: 11883101]

9. Levy DP, Navarro JM, Schattman GL, Davis OK, Rosenwaks Z. The role of LH in ovarian stimulation: exogenous LH: let's design the future. Hum Reprod. 2000; 15(11):2258-65. [PubMed: 11056116]

10. Colonna R, Mangia F. Mechanisms of amino acid uptake in cumulus-enclosed mouse oocytes. Biol Reprod. 1983; 28(4):797-803. [PubMed: 6860738]

11. Haghighat N, Van Winkle LJ. Developmental change in follicular cell-enhanced amino acid uptake into mouse oocytes that depends on intact gap junctions and transport system Gly. J Exp Zool. 1990; 253(1):71-82. [PubMed: 2313243]

12. Furger C, Cronier L, Poirot C, Pouchelet M. Human granulosa cells in culture exhibit functional cyclic AMP-regulated gap junctions. Mol Hum Reprod. 1996; 2(8):541-8. [PubMed: 9239665]

13. Sela-Abramovich S, Edry I, Galiani D, Nevo N, Dekel N. Disruption of gap junctional communication within the ovarian follicle induces oocyte maturation. Endocrinology. 2006; 147(5):2280-6. [PubMed: 16439460]

14. Saito T, Hiroi M, Kato T. Development of glucose utilization studied in single oocytes and preimplantation embryos from mice. Biol Reprod. 1994; 50(2):266-70. [PubMed: 8142545]

15. Johnson MT, Freeman EA, Gardner DK, Hunt PA. Oxidative metabolism of pyruvate is required for meiotic maturation of murine oocytes in vivo. Biol Reprod. 2007; 77(1):2, 8. [PubMed: 17314311]

16. Gilchrist RB, Nayudu PL, Nowshari MA, Hodges JK. Meiotic competence of marmoset monkey oocytes is related to follicle size and oocyte-somatic cell associations. Biol Reprod. 1995; 52(6): 1234-43. [PubMed: 7632831]

17. Zeleznik AJ. The physiology of follicle selection. Reprod Biol Endocrinol. 2004; 2:31. [PubMed: 15200680]

18. Fuller B, Paynter S. Fundamentals of cryobiology in reproductive medicine. Reprod Biomed Online. 2004; 9(6):680-91. [PubMed: 15670420]

19. Mullen, SF.; Critser, JK. The science of cryobiology. In: Woodruff, TK.; Snyder, KA., editors. Oncofertility: fertility preservation for cancer survivors. New York: Springer; 2007. p. 83-103.

20. Mazur P. Slow-freezing injury in mammalian cells. Ciba Found Symp. 1977; 52:19-48. [PubMed: 244395]

21. Whittingham DG. Some factors affecting embryo storage in laboratory animals. Ciba Found Symp. 1977; 52:97-127. [PubMed: 244403]

22. Leibo SP. Fundamental cryobiology of mouse ova and embryos. Ciba Found Symp. 1977; 52:6996. [PubMed: 244402]

23. Leibo SP, McGrath JJ, Cravalho EG. Microscopic observation of intracellular ice formation in unfertilized mouse ova as a function of cooling rate. Cryobiology. 1978; 15(3):257-71. [PubMed: 710156]

24. Mazur P, Leibo SP, Chu EH. A two-factor hypothesis of freezing injury. Evidence from Chinese hamster tissue-culture cells. Exp Cell Res. 1972; 71(2):345-55. [PubMed: 5045639]

25. Lovelock JE. The haemolysis of human red blood-cells by freezing and thawing. Biochim Biophys Acta. 1953; 10(3):414-26. [PubMed: 13058999]

26. Lovelock JE. The mechanism of the protective action of glycerol against haemolysis by freezing and thawing. Biochim Biophys Acta. 1953; 11(1):28-36. [PubMed: 13066452]

27. De Santis L, Coticchio G, Paynter S, Albertini D, Hutt K, Cino I, Iaccarino M, Gambardella A, Flamigni C, Borini A. Permeability of human oocytes to ethylene glycol and their survival and spindle configurations after slow cooling cryopreservation. Hum Reprod. 2007; 22(10):2776-83. [PubMed: 17675355] 
28. Karlsson JO, Younis AI, Chan AW, Gould KG, Eroglu A. Permeability of the rhesus monkey oocyte membrane to water and common cryoprotectants. Mol Reprod Dev. 2009; 76(4):321-33. [PubMed: 18932214]

29. Liu J, Mullen S, Meng Q, Critser J, Dinnyes A. Determination of oocyte membrane permeability coefficients and their application to cryopreservation in a rabbit model. Cryobiology. 2009; 59(2): 127-34. [PubMed: 19527701]

30. Jackowski S, Leibo SP, Mazur P. Glycerol permeabilities of fertilized and infertilized mouse ova. J Exp Zool. 1980; 212(3):329-41. [PubMed: 7420045]

31. Kasai M, Iritani A, Chang MC. Fertilization in vitro of rat ovarian oocytes after freezing and thawing. Biol Reprod. 1979; 21(4):839-44. [PubMed: 526504]

32. Pedro PB, Yokoyama E, Zhu SE, Yoshida N, Valdez DM Jr, Tanaka M, Edashige K, Kasai M. Permeability of mouse oocytes and embryos at various developmental stages to five cryoprotectants. J Reprod Dev. 2005; 51(2):235-46. [PubMed: 15883485]

33. Songsasen N, Yu IJ, Ratterree MS, VandeVoort CA, Leibo SP. Effect of chilling on the organization of tubulin and chromosomes in rhesus monkey oocytes. Fertil Steril. 2002; 77(4): 818-25. [PubMed: 11937140]

34. Paynter SJ, O'Neil L, Fuller BJ, Shaw RW. Membrane permeability of human oocytes in the presence of the cryoprotectant propane-1,2-diol. Fertil Steril. 2001; 75(3):532-8. [PubMed: 11239537]

35. Fuller BJ, Paynter SJ. Cryopreservation of mammalian embryos. Methods Mol Biol. 2007; 368:325-39. [PubMed: 18080481]

36. Trad FS, Toner M, Biggers JD. Effects of cryoprotectants and ice-seeding temperature on intracellular freezing and survival of human oocytes. Hum Reprod. 1999; 14(6):1569-77. [PubMed: 10357978]

37. Younis AI, Toner M, Albertini DF, Biggers JD. Cryobiology of non-human primate oocytes. Hum Reprod. 1996; 11(1):156-65. [PubMed: 8671179]

38. Karlsson JO, Eroglu A, Toth TL, Cravalho EG, Toner M. Fertilization and development of mouse oocytes cryopreserved using a theoretically optimized protocol. Hum Reprod. 1996; 11(6):1296305. [PubMed: 8671443]

39. Toner M, Cravalho EG, Armant DR. Water transport and estimated transmembrane potential during freezing of mouse oocytes. J Membr Biol. 1990; 115(3):261-72. [PubMed: 2374161]

40. Pegg DE. Principles of cryopreservation. Methods Mol Biol. 2007; 368:39-57. [PubMed: 18080461]

41. Fabbri R. Cryopreservation of human oocytes and ovarian tissue. Cell Tissue Bank. 2006; 7(2): 113-22. [PubMed: 16732414]

42. Fabbri R, Pasquinelli G, Bracone G, Orrico C, Di Tommaso B, Venturoli S. Cryopreservation of human ovarian tissue. Cell Tissue Bank. 2006; 7(2):123-33. [PubMed: 16732415]

43. Shaw, JM. Cryopreservation of oocytes and embryos. In: Trounson, AO.; Gardner, DK., editors. Handbook of in vitro fertilization. 2. Boca Raton: CRC Press LLC; 2000. p. 373-68.

44. Gracia, CR.; Ginsberg, JP. Fertility risk in pediatric and adolescent cancers. In: Woodruff, TK.; Snyder, KA., editors. Oncofertility: fertility preservation fro cancer survivors. New York: Springer; 2007. p. 57-68.

45. Ostensen M, Khamashta M, Lockshin M, Parke A, Brucato A, Carp H, Doria A, Rai R, Meroni P, Cetin I, Derksen R, Branch W, Motta M, Gordon C, Ruiz-Irastorza G, Spinillo A, Friedman D, Cimaz R, Czeizel A, Piette JC, Cervera R, Levy RA, Clementi M, De Carolis S, Petri M, Shoenfeld Y, Faden D, Valesini G, Tincani A. Anti-inflammatory and immunosuppressive drugs and reproduction. Arthritis Res Ther. 2006; 8(3):209. [PubMed: 16712713]

46. Chen SH, Wallach EE. Five decades of progress in management of the infertile couple. Fertil Steril. 1994; 62(4):665-85. [PubMed: 7926072]

47. Lee SJ, Schover LR, Partridge AH, Patrizio P, Wallace WH, Hagerty K, Beck LN, Brennan LV, Oktay K. American Society of Clinical Oncology recommendations on fertility preservation in cancer patients. J Clin Oncol. 2006; 24(18):2917-31. [PubMed: 16651642]

48. Medicine TECotASfR. Fertility preservation and reproduction in cancer patients. Report nr. 15565653 (Electronic). 2005:1622-8. 
49. Whittingham DG, Leibo SP, Mazur P. Survival of mouse embryos frozen to -196 degrees and 269 degrees C. Science. 1972; 178(59):411-4. [PubMed: 5077328]

50. Wilmut I. The effect of cooling rate, warming rate, cryoprotective agent and stage of development on survival of mouse embryos during freezing and thawing. Life Sci II. 1972; 11(22):1071-9. [PubMed: 4663808]

51. Steptoe PC, Edwards RG. Birth after the reimplantation of a human embryo. Lancet. 1978; 2(8085):366. [PubMed: 79723]

52. Cohen J, Simons RF, Edwards RG, Fehilly CB, Fishel SB. Pregnancies following the frozen storage of expanding human blastocysts. J In Vitro Fert Embryo Transf. 1985; 2(2):59-64.

53. Cohen J, Simons RF, Fehilly CB, Fishel SB, Edwards RG, Hewitt J, Rowlant GF, Steptoe PC, Webster JM. Birth after replacement of hatching blastocyst cryopreserved at expanded blastocyst stage. Lancet. 1985; 1(8429):647. [PubMed: 2857991]

54. Trounson A, Mohr L. Human pregnancy following cryopreservation, thawing and transfer of an eight-cell embryo. Nature. 1983; 305(5936):707-9. [PubMed: 6633637]

55. Services UDoHaH. Assisted reproductive technology (ART). Atlanta: Center for Disease Control and Prevention; 2007. Pregnancy success rates from frozen embryos from non-donor eggs.

56. Kuwayama M. Highly efficient vitrification for cryopreservation of human oocytes and embryos: the Cryotop method. Theriogenology. 2007; 67(1):73-80. [PubMed: 17055564]

57. Stehlik E, Stehlik J, Katayama KP, Kuwayama M, Jambor V, Brohammer R, Kato O. Vitrification demonstrates significant improvement versus slow freezing of human blastocysts. Reprod Biomed Online. 2005; 11(1):53-7. [PubMed: 16102287]

58. Medicine TPCotASfR. Ovarian tissue and oocyte cryopreservation. Fertil Steril. 2004; 82(4):9938. [PubMed: 15482797]

59. Aigner S, Van der Elst J, Siebzehnrubl E, Wildt L, Lang N, Van Steirteghem AC. The influence of slow and ultra-rapid freezing on the organization of the meiotic spindle of the mouse oocyte. Hum Reprod. 1992; 7(6):857-64. [PubMed: 1500486]

60. Gook DA, Osborn SM, Bourne H, Johnston WI. Fertilization of human oocytes following cryopreservation; normal karyotypes and absence of stray chromosomes. Hum Reprod. 1994; 9(4): 684-91. [PubMed: 8046024]

61. Cobo A, Kuwayama M, Perez S, Ruiz A, Pellicer A, Remohi J. Comparison of concomitant outcome achieved with fresh and cryopreserved donor oocytes vitrified by the Cryotop method. Fertil Steril. 2008; 89(6):1657-64. [PubMed: 17889865]

62. Oktay K, Cil AP, Bang H. Efficiency of oocyte cryopreservation: a meta-analysis. Fertil Steril. 2006; 86(1):70-80. [PubMed: 16818031]

63. Chian RC, Gilbert L, Huang JY, Demirtas E, Holzer H, Benjamin A, Buckett WM, Tulandi T, Tan SL. Live birth after vitrification of in vitro matured human oocytes. Fertil Steril. 2009; 91(2):3726. [PubMed: 18514195]

64. Chian RC, Huang JY, Gilbert L, Son WY, Holzer H, Cui SJ, Buckett WM, Tulandi T, Tan SL. Obstetric outcomes following vitrification of in vitro and in vivo matured oocytes. Fertil Steril. 2009; 91(6):2391-8. [PubMed: 18579139]

65. Katayama KP, Stehlik J, Kuwayama M, Kato O, Stehlik E. High survival rate of vitrified human oocytes results in clinical pregnancy. Fertil Steril. 2003; 80(1):223-4. [PubMed: 12849831]

66. Kuwayama M, Vajta G, Kato O, Leibo SP. Highly efficient vitrification method for cryopreservation of human oocytes. Reprod Biomed Online. 2005; 11(3):300-8. [PubMed: 16176668]

67. Nugent D, Meirow D, Brook PF, Aubard Y, Gosden RG. Transplantation in reproductive medicine: previous experience, present knowledge and future prospects. Hum Reprod Update. 1997; 3(3):267-80. [PubMed: 9322102]

68. Donnez J, Bassil S. Indications for cryopreservation of ovarian tissue. Hum Reprod Update. 1998; 4(3):248-59. [PubMed: 9741709]

69. Meirow D. Ovarian injury and modern options to preserve fertility in female cancer patients treated with high dose radio-chemotherapy for hemato-oncological neoplasias and other cancers. Leuk Lymphoma. 1999; 33(1-2):65-76. [PubMed: 10194122] 
70. Schmidt KL, Byskov AG, Nyboe Andersen A, Muller J, Yding Andersen C. Density and distribution of primordial follicles in single pieces of cortex from 21 patients and in individual pieces of cortex from three entire human ovaries. Hum Reprod. 2003; 18(6):1158-64. [PubMed: 12773440]

71. Parrot DMV. The fertility of mice with orthotopic ovariam grafts derived from frozen tissue. J Reprod Fertil. 1960; 1:230-41.

72. Sztein J, Sweet H, Farley J, Mobraaten L. Cryopreservation and orthotopic transplantation of mouse ovaries: new approach in gamete banking. Biol Reprod. 1998; 58(4):1071-4. [PubMed: 9546742]

73. Gosden RG, Baird DT, Wade JC, Webb R. Restoration of fertility to oophorectomized sheep by ovarian autografts stored at -196 degrees C. Hum Reprod. 1994; 9(4):597-603. [PubMed: 8046009]

74. Lee DM, Yeoman RR, Battaglia DE, Stouffer RL, Zelinski-Wooten MB, Fanton JW, Wolf DP. Live birth after ovarian tissue transplant. Nature. 2004; 428(6979):137-8. [PubMed: 15014485]

75. Oktay K, Economos K, Kan M, Rucinski J, Veeck L, Rosenwaks Z. Endocrine function and oocyte retrieval after autologous transplantation of ovarian cortical strips to the forearm. JAMA. 2001; 286(12):1490-3. [PubMed: 11572742]

76. Kiran G, Kiran H, Coban YK, Guven AM, Yuksel M. Fresh autologous transplantation of ovarian cortical strips to the anterior abdominal wall at the pfannenstiel incision site. Fertil Steril. 2004; 82(4):954-6. [PubMed: 15482779]

77. Donnez J, Dolmans MM, Demylle D, Jadoul P, Pirard C, Squifflet J, Martinez-Madrid B, van Langendonckt A. Livebirth after orthotopic transplantation of cryopreserved ovarian tissue. Lancet. 2004; 364(9443):1405-10. [PubMed: 15488215]

78. Meirow D, Levron J, Eldar-Geva T, Hardan I, Fridman E, Zalel Y, Schiff E, Dor J. Pregnancy after transplantation of cryopreserved ovarian tissue in a patient with ovarian failure after chemotherapy. N Engl J Med. 2005; 353(3):318-21. [PubMed: 15983020]

79. Donnez J, Squifflet J, Van Eyck AS, Demylle D, Jadoul P, Van Langendonckt A, Dolmans MM. Restoration of ovarian function in orthotopically transplanted cryopreserved ovarian tissue: a pilot experience. Reprod Biomed Online. 2008; 16(5):694-704. [PubMed: 18492374]

80. Gougeon A. Regulation of ovarian follicular development in primates: facts and hypotheses. Endocr Rev. 1996; 17(2):121-55. [PubMed: 8706629]

81. Andersen CY, Rosendahl M, Byskov AG, Loft A, Ottosen C, Dueholm M, Schmidt KL, Andersen AN, Ernst E. Two successful pregnancies following autotransplantation of frozen/thawed ovarian tissue. Hum Reprod. 2008; 23(10):2266-72. [PubMed: 18603535]

82. Donnez J, Squifflet J, Dolmans MM, Martinez-Madrid B, Jadoul P, Van Langendonckt A. Orthotopic transplantation of fresh ovarian cortex: a report of two cases. Fertil Steril. 2005; 84(4): 1018. [PubMed: 16213862]

83. Callejo J, Salvador C, Miralles A, Vilaseca S, Lailla JM, Balasch J. Long-term ovarian function evaluation after autografting by implantation with fresh and frozen-thawed human ovarian tissue. J Clin Endocrinol Metab. 2001; 86(9):4489-94. [PubMed: 11549698]

84. Oktay K, Karlikaya G. Ovarian function after transplantation of frozen, banked autologous ovarian tissue. N Engl J Med. 2000; 342(25):1919. [PubMed: 10877641]

85. Demeestere I, Simon P, Emiliani S, Delbaere A, Englert Y. Orthotopic and heterotopic ovarian tissue transplantation. Hum Reprod Update. 2009; 15(6):649-65. [PubMed: 19474206]

86. Radford J. Autotransplantation of ovarian tissue and the risk of disease transmission. Eur J Obstet Gynecol Reprod Biol. 2004; 113(Suppl 1):S14-S16. [PubMed: 15041124]

87. Shaw JM, Bowles J, Koopman P, Wood EC, Trounson AO. Fresh and cryopreserved ovarian tissue samples from donors with lymphoma transmit the cancer to graft recipients. Hum Reprod. 1996; 11(8):1668-73. [PubMed: 8921114]

88. Woods EJ, Benson JD, Agca Y, Critser JK. Fundamental cryobiology of reproductive cells and tissues. Cryobiology. 2004; 48(2):146-56. [PubMed: 15094091]

89. Barrett SL, Shea LD, Woodruff TK. Noninvasive index of cryorecovery and growth potential for human follicles in vitro. Biol Reprod. 2010; 82(6):1180-1189. [PubMed: 20200211] 
90. Dolmans MM, Michaux N, Camboni A, Martinez-Madrid B, Van Langendonckt A, Nottola SA, Donnez J. Evaluation of Liberase, a purified enzyme blend, for the isolation of human primordial and primary ovarian follicles. Hum Reprod. 2006; 21(2):413-20. [PubMed: 16199426]

91. Kreeger PK, Fernandes NN, Woodruff TK, Shea LD. Regulation of mouse follicle development by follicle-stimulating hormone in a three-dimensional in vitro culture system is dependent on follicle stage and dose. Biol Reprod. 2005; 73(5):942-50. [PubMed: 15987824]

92. Xu M, Woodruff TK, Shea LD. Bioengineering and the ovarian follicle. Cancer Treat Res. 2007; 138:75-82. [PubMed: 18080658]

93. Xu M, Banc A, Woodruff TK, Shea LD. Secondary follicle growth and oocyte maturation by culture in alginate hydrogel following cryopreservation of the ovary or individual follicles. Biotechnol Bioeng. 2009; 103(2):378-86. [PubMed: 19191350]

94. West ER, Xu M, Woodruff TK, Shea LD. Physical properties of alginate hydrogels and their effects on in vitro follicle development. Biomaterials. 2007; 28(30):4439-48. [PubMed: 17643486]

95. Xu M, Kreeger PK, Shea LD, Woodruff TK. Tissue-engineered follicles produce live, fertile offspring. Tissue Eng. 2006; 12(10):2739-46. [PubMed: 17518643]

96. West-Farrell ER, Xu M, Gomberg MA, Chow YH, Woodruff TK, Shea LD. The mouse follicle microenvironment regulates antrum formation and steroid production: alterations in gene expression profiles. Biol Reprod. 2008; 80(3):432-9. [PubMed: 19005169]

97. Picton HM, Harris SE, Muruvi W, Chambers EL. The in vitro growth and maturation of follicles. Reproduction. 2008; 136(6):703-15. [PubMed: 19074213]

98. Xu M, West-Farrell ER, Stouffer RL, Shea LD, Woodruff TK, Zelinski MB. Encapsulated threedimensional culture supports development of nonhuman primate secondary follicles. Biol Reprod. 2009; 81(3):587-94. [PubMed: 19474063]

99. Xu M, Barrett SL, West-Farrell E, Kondapalli LA, Kiesewetter SE, Shea LD, Woodruff TK. In vitro grown human ovarian follicles from cancer patients support oocyte growth. Hum Reprod. 2009; 24(10):2531-2540. [PubMed: 19597190] 


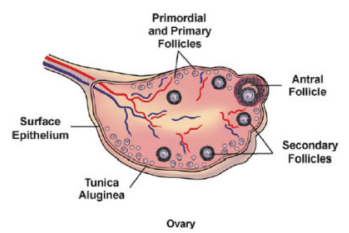

Fig. 3.1.

A human ovary showing the blood supply feeding the arrangement of follicles within the ovarian cortex 

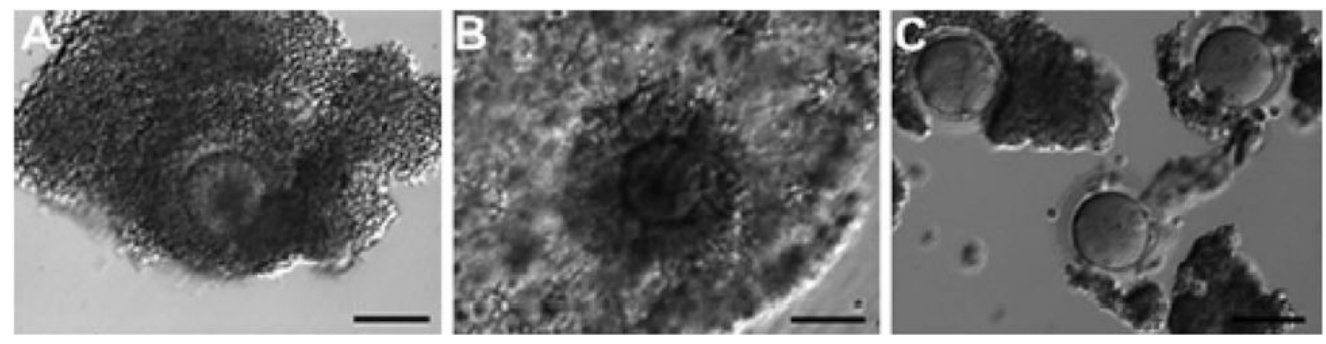

Fig. 3.2.

Human cumulus-oocyte complexes isolated from large antral follicles during the tissue collection process at $0 \mathrm{~h}(\mathbf{a}), 24 \mathrm{~h}(\mathbf{b})$, and $40 \mathrm{~h}$ (c) during the in vitro maturation process. Black measurement bar represents $100 \mu \mathrm{m}$ 

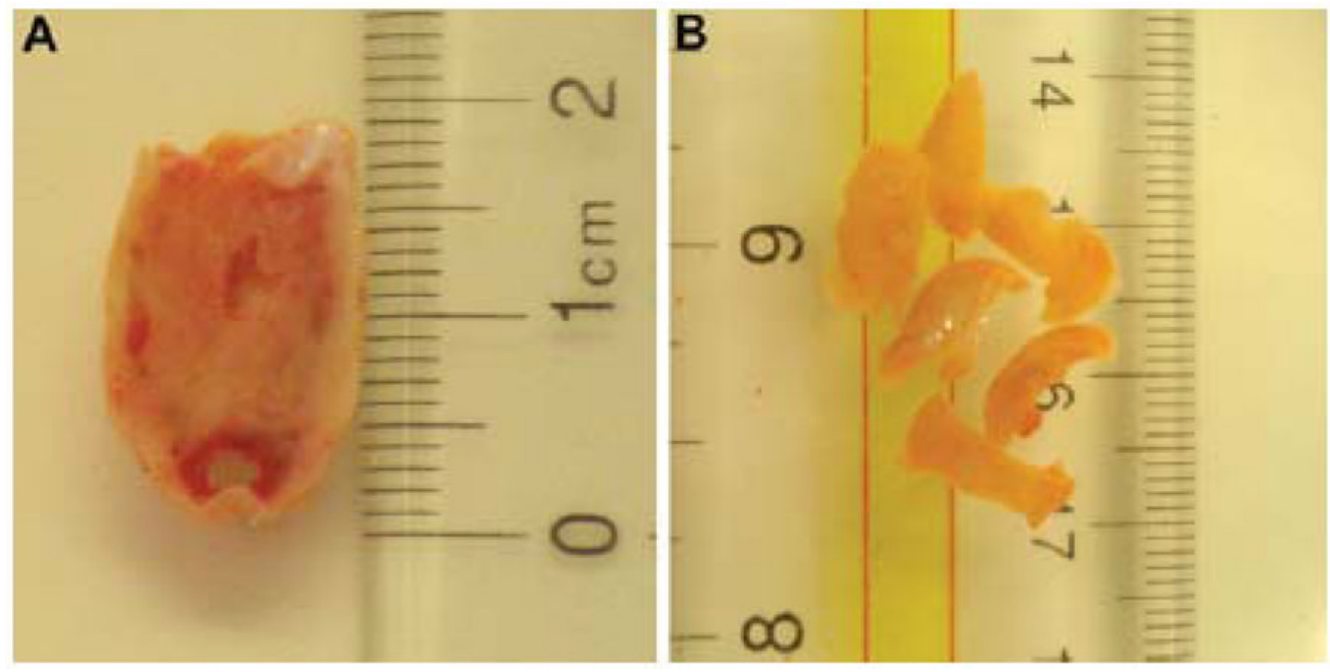

Fig. 3.3.

Bisected human ovary showing the thick outer cortex and the inner vascular medulla (a). Human ovarian cortex cut into strips prior to cryopreservation (b) 

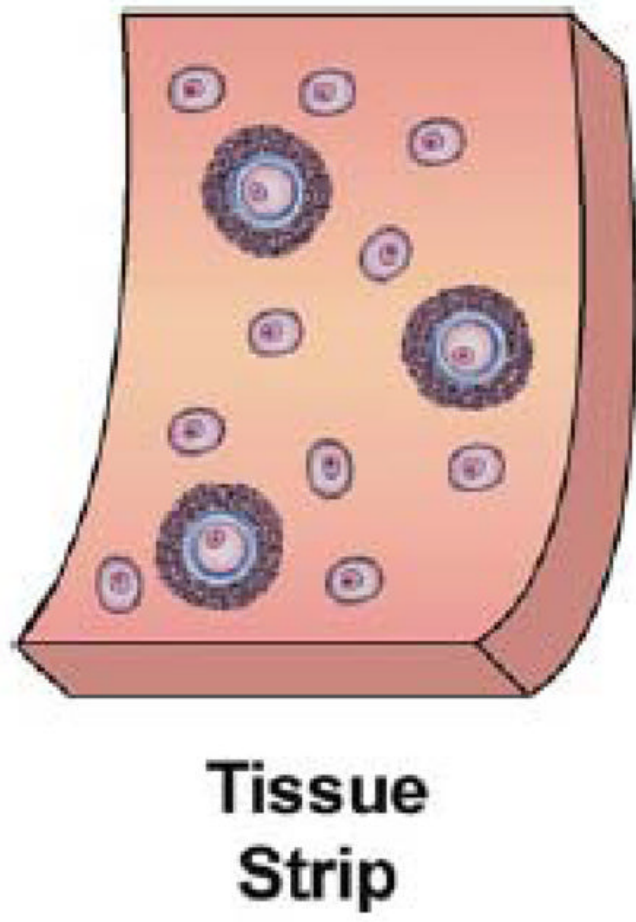

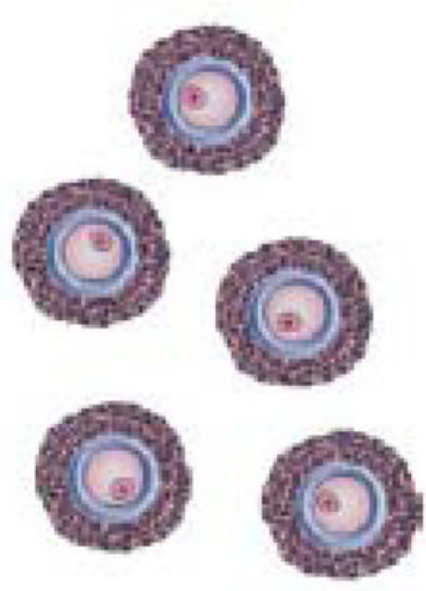

Secondary Follicles

Fig. 3.4.

The ovary is dissected into tissue pieces that are either cryopreserved or treated with collagenase for the dissection of secondary follicles used for in vitro follicle growth 